\title{
AFFECTED COMMUNITIES - RISING SOCIAL DISPARITIES FORMULATING A BALANCE BETWEEN MAINTAINING UNIQUE VALUE OF AN ESTABLISHED COMMUNITY AND THE NEEDS TO IMPROVE ITS QUALITY OF LIFE - A CASE STUDY OF KAMPONG BHARU; A TRADITIONAL URBAN VILLAGE IN KUALA LUMPUR, MALAYSIA
}

\author{
Abd Muluk Bin Abd Manan*
}

\begin{abstract}
The Kampong Bharu community was established by the Colonial British government in the late nineteenth century as a 'Malay Agricultural Settlement' - a riverside area strategically removed from the old city centre of Kuala Lumpur, where many of the economic activities fuelled the city's early growth. Ethnic Malay families from several villages were relocated here and given exclusive land rights to maintain a 'village life'.

Due to complex land rights enactment, entitlements and inheritance laws, many parcels in this neighbourhood have remained untouched for more than a century. The appearance and lifestyle associated with Kampong Bharu today are seemingly at odds with a city that aggressively grows around it. This paper explores the neighbourhood and documents the complexities and contradictions of urban development that the area encapsulates.
\end{abstract}

Kampong Bharu today sits in the heart of the city. Many parcels of the land have changed ownership. The agricultural land with its modest original house gradually expanded into a sprawling, ramshackle home for dozens of extended families. It has become the hotspot for resettlement for new urban migrants that come to the city to resettle during pre and postindependence. Many historical events have happened here and it has become one of the most well-known neighbourhood in the city.

Efforts by the authority to develop this area failed due to various reasons. They had tried to establish a balance between the concerns of long-term inhabitants and the demands of modern development. This paper examines the reasons and also explores how stakeholders in Kampong Bharu have been involved in recent redevelopment efforts. Key stakeholders including landowners, residents, village heads, and leaders of local associations were interviewed, and their concerns and aspirations were documented.

\section{INTRODUCTION}

Formulating a balance between maintaining unique value of an established community and the needs to improve its quality of life is not an easy task. In an established urban village, like Kampong Bharu, certain values will definitely be lost in the face of new development (figure 1). The pace of urbanization in East Asia is at the rate of three percent and the rate of expansion in major cities like Kuala Lumpur has

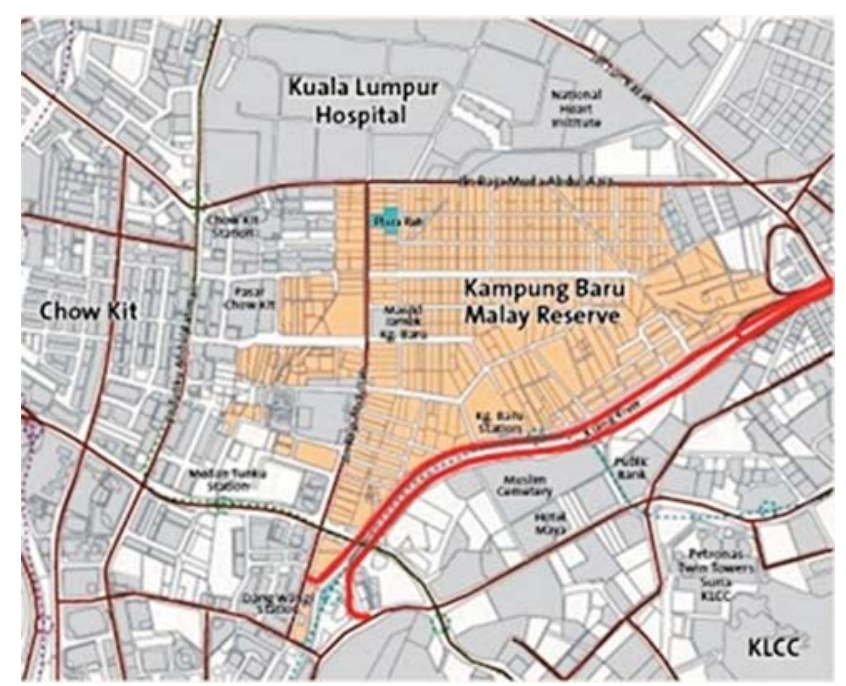

Figure 1: Map of Kampong Bharu

* Abd Muluk Bin Abd Manan, Universiti Tunku Abdul Rahman Kuala Lumpur, Malaysia Email correspondence: abdmuluk@utar.edu.my 


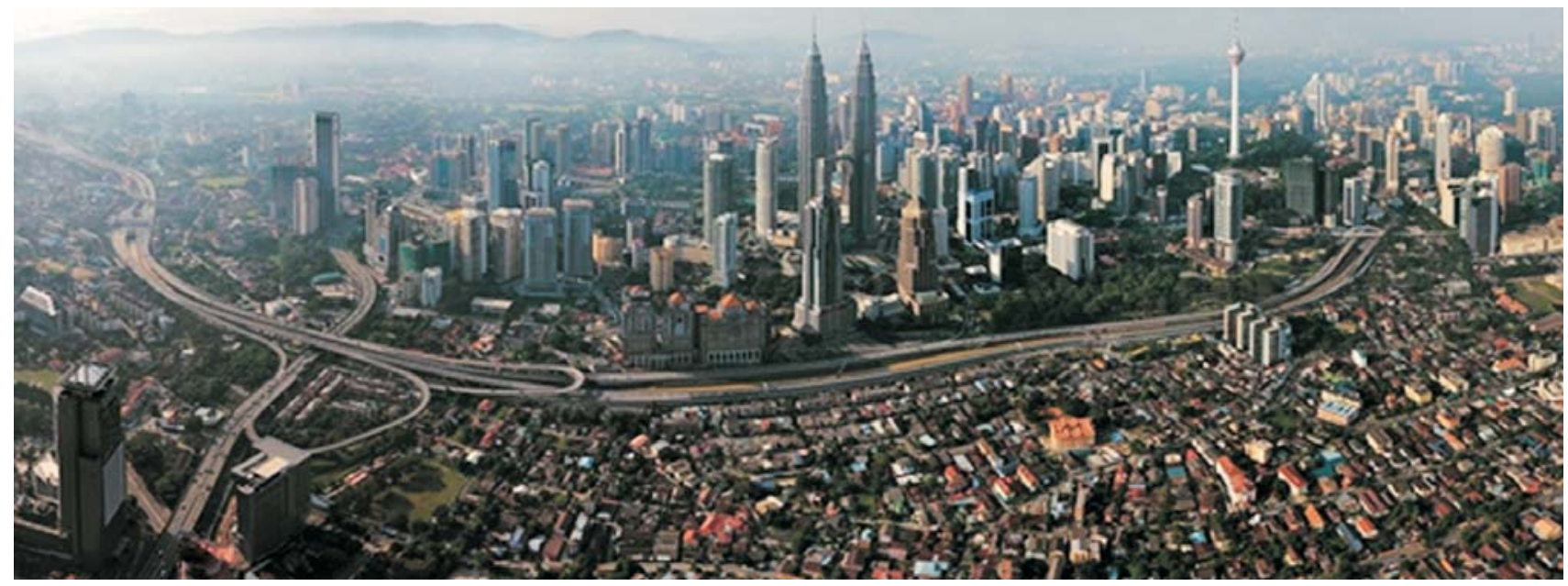

Figure 2: A view of Kampong Bharu.

reached two and a half percent per year (figure 2) (World Bank, 2016). An initiative by the Malaysian Government which started in September 1978, to study how to develop the area, lead to the formation of Kampong Bharu Development Corporation (PKB) under a Parliamentary Act 733 in 2012, to facilitate the implementation of the development plan for this area. A Comprehensive Development Masterplan was prepared in 2014 and the planning process was initiated (DBKL, 2004).

Kampong Bharu began in the early 1900s when the Sultan of Selangor granted the land to the Malays under a special condition that only Malays could own the land and reside in the area. "Malay" means a person belonging to any Malay race who habitually speaks the language, professes Islam and practices its custom. A kampong is defined as a Malay hamlet or village in a Malay-speaking country, determined as a locality with ten thousand or fewer people. The terms of the special status of Kampong Bharu as Malay Agriculture Land (MAS) made this area protected against development. Over the years, the strain of being located in the middle of a fast-developing city and exploding population in the late sixties and seventies has taken its toll on the infrastructure and the quality of life.

Kampong Bharu houses five thousand and three hundred registered landowners owning eight hundred and ninety parcels of land with a total population of eighteen thousand people in seven villages. The challenges of developing this area among others are lack of infrastructure and community facilities to support big development. Despite piecemeal development and additions to building and houses, the kampong looks much as it did one hundred and twenty years ago. Traditional houses, small businesses, local food and delicacies have shaped its unique character. Haphazard parked vehicles in front of houses and shops and narrow alleyways also becomes a distinct character of the place.

With only about thirty five percent of its original residents remaining, the area has become a hybrid community. The arrival of people from other parts of Malaysia has resulted in the emergence of a transient community with a potentially weaker sense of place. The village has been subjected to incremental and unregulated development with little effort made to protect the character of the original kampong. Illegal extension and additional structures have been built around the original kampung houses (figure 3 ).

The concerns related to the development of this locality focus on the impact of new development on land values, ways of taking into account the multiple and shared ownership of land, the adverse impact of new development on patterns of everyday lives, and questions about who should make the final decisions. The sustainability of an urban village depends in part on how people are informed about and engaged in the allocation of economic and social benefits. Giving greater voice to the people in such villages, especially in cities that are developing, could better align city redevelopment objectives with the interests and values of people living in traditional enclaves to tackle social disparities (Wiryomartono, 2013). 


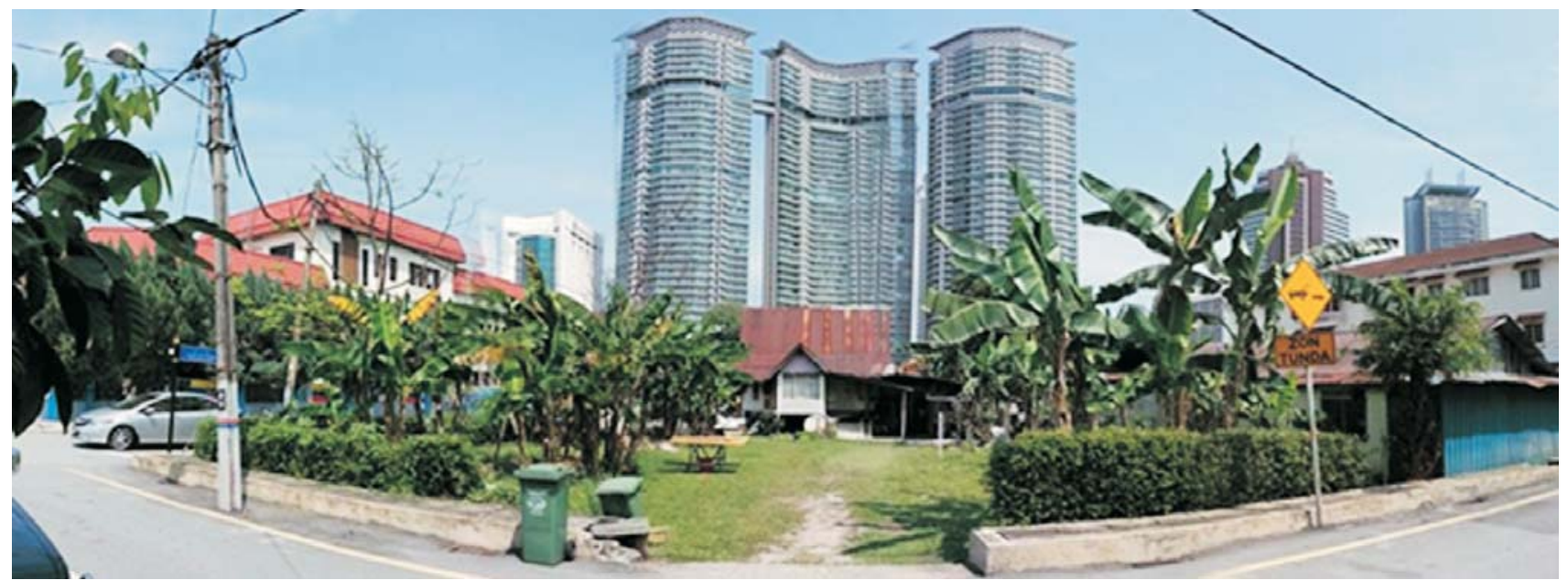

Figure 3: Social disparities, contrasting lifestyles.

\section{THE AIM AND METHODOLOGY}

The methodology employed for this study relies on empirical field work that utilizes personal observation, interviews of stakeholders and questionnaire survey by architecture students between the period 2014-2016. The study also includes secondary data analysis which involved documents related to Kampong Bharu, including online resources, government reports and guidelines, journal articles, and books. The recent Master Plan of Kampong Bharu Development provided an understanding of planning and development strategies. In addition, semi-structured interviews guided by a list of questions were conducted among the members of the community. Key interviewees identified included professionals from local authority (PKB), village heads, leaders of the local association, and residents of Kampong Bharu. The researcher noted that some key interviewees held multiple roles in the community.

The aim of this study was to produce a comprehensive development plan outlining complete perspective, ethics and strategic moves in managing a sustainable development of Kampong Bharu. The objectives of the research were:

1. To identify the expectations of the locals regarding the improvement that they are going to benefit from in any proposed development.

2. To further enhance the redevelopment by taking into account the ideas and proposals from local residences.
3. To determine the types of development that would be suitable for Kampong Bharu.

4. To identify zones that would be given development priority based on the agreement of the land owners.

5. To propose layout and physical development design strategies that would be implemented, based on the development phasing.

\section{KAMPONG BHARU UNIQUE VALUES}

\section{Historically}

The area held a special place for Malay politics during the pro-independence movement that grew up after. Anti-colonial protests were held here, and founders of Malaysia's dominant political party, had origins at the Sultan Sulaiman Club in Kampong Bharu, and held their early meetings here according to the Culture, Arts and Heritage Minister . It also played a part in 1969, where bloody racial clashes occurred between ethnic Malays and Chinese. The riots started after Chineseled opposition parties marched through the village to celebrate their good showing in general elections of that year. In recent years, Kampong Bharu has also played a central role in the protests of 1998, when former deputy premier launched protests against the then premier, calling for reforms of the government and its judiciary (Mohamed and Zen, 2000). 


\section{Cultural and Heritage}

Kampong Bharu may very well be the last standing Malay village in Kuala Lumpur. This historic establishment, surrounded by the towering skyscrapers of the city, still thrive as a living testament to Malaysia's beginnings, current development and the future. The village is now part of an important tourist attraction featuring the living heritage and culture of Malaysia. The sense of place is defined by its physical fabric, also by its socio-cultural characteristics. Bunnel in "Kampong Rules" (Wiryomartono, 2013), refer to kampong as a place of traditional values, high morality, a space of resistance to the often-alienating project of modernisation, a space of community support, neighbourliness and pride in community (Fujita, 2010).

Kuala Lumpur Tourism Bureau organises walking tours that take visitors down the memory lane. The heritage walk takes tourists to several important sites to see a traditional Malay house built in 1921, known as Master Mat's house at the Kelab Sultan Suleiman Gallery, which showcases the history of the Malay political struggle, the Gurdwara Tatt Khalsa and the Jamek Mosque. The walk passes by many surviving old wooden houses and rows of traditional shops and along the way basic Malay customs and traditions are observed.

Kampong Bharu is also a thriving foodies' paradise and has brought renewed attention to the kampung life in Kuala Lumpur. Tourists have the opportunity to try out popular street-food such as bubor lambok (spiced rice porridge), kuih-muih (traditional cakes and sweets) and the famous Nasi lemak antarabangsa at the Malay food street. During Ramadhan, Kampong Bharu is flooded with people from all corners of the city to its food bazaar for traditional delicacies for iftar and late supper.

However, in the current context of Neoliberalism, the allocation of spatial, political and economic resources tends to favour economic growth rather than embracing social benefits that are widely shared (Fainstein, 2012).

\section{THE VISION}

The vision of PKB is to develop and transform the real estate in creating a better-living standard while balancing the requirement to preserve the historical values, culture and legacy (PKB, 2014). The mission was that no landowner or heir of the land would be left behind in this development beyond 2020 (PKB, 2014). The plan was expected to create a new economic and cultural enclave for the city. Inspired by the Malay and Islamic culture, the master plan was designed to ensure holistic, inclusive and balanced planning that gave positive impact to the key stakeholders in Kampong Bharu (PKB, 2014), indicating the importance of preserving Kampong Bharu's identity and recognizing that the landowners and inhabitants were an integral part of the development process.

The government foresaw Kampong Bharu becoming a new Malay urban centre, which could increase the social and economic status of the Malays. The Prime Minister emphasised this point in a speech: "I want the Malays in Kampong Bharu to have economic and social status that we can be proud of, because the concept behind the development of Kampong Bharu is that the Malays are not excluded from mainstream national development" (Speech by Prime Minister of Malaysia, $18^{\text {th }}$ Oct 2015). Public involvement and participation can help the community exercise its power as a unified group in the face of proposed development (Marilyn, 2007).

Dato' Zahari Affendi, Chairman of the PKB, addressed the challenges in transforming the urban village. His observations indicated that things weren't necessarily going according to plan: "We have started this process and are talking to several local developers to see how they can help the Kampong Bharu people to unlock the value of the land. This is not easy, as there are many lots with multiple owners" (New Straits Times, 2016). The extent of the proposed changes was well described in the following statement: "After more than a century of being stuck in time, Kampong Bharu is set for dramatic changes that will see several ambitious projects coming up in the Malay enclave in the next ten to twenty years. Skyscrapers and pocket parks are among highlights of the town facelift". Besides the main quest to develop a comprehensive plan for Kampong Bharu beyond 2020, the PKB is also undertaking quick win projects focusing on upgrading certain areas to improve the village's image and identity. This effort is seen as crucial in attracting the owners, beneficiaries and investors to invest in the development of Kampong Bharu.

The PKB's Deputy Director of Urban Planning, Encik Zamri Mohammed Saharin, made the argument that 
the redevelopment would be a virtuous circle, fuelling itself for the benefit of all stakeholders. The negative image and perception of the village as a "slum" would soon be changed, thanks to modern and high-density developments surrounding the area. The landowners and residents would enjoy great economic benefit, due to the rising value of their properties and potential development opportunities (PKB, 2014).

\section{PHYSICAL DEVELOPMENT STRATEGY}

In order to coordinate the physical development, a joint Inclusive Trust Board (ITB) would be formed to lead the main developer for master planning to form a Development Trust Board (DTB), where the execution would be meted out by the Development Trust Board. Selected representatives from government agencies, subsequent co-developer, alongside the main developer shall form the DTB. The main developer shall play the role of Project Delivery Partner, which would mean that they would assume the role and ownership of the project till the delivery of the project. The transitionary administration of the project site shall be under the corporatized branch of DTB, as a transitionary local authority (PKB, 2014).

\section{IMPLEMENTATION}

The latest implementation strategy adopted by PKB is to broadly divide the area into three zones. They have been identified through planning and implementation method, that have been adapted to suit the existing situation.

ZONE-A: Development through lot amalgamation ZONE-B: Comprehensive development ZONE-C: Development through 'Business Improvement District Scheme’ (BIDS) Programme.

\section{FINDING AND RESULTS}

Currently all the three zones have started implementing development strategies with mix results. There is limited success in persuading the land owner on Zone A to amalgamate their small piece of land with their neighbours. Engagement with all stake holders are still ongoing and the full result will only be known in years to come (figure 4 ).

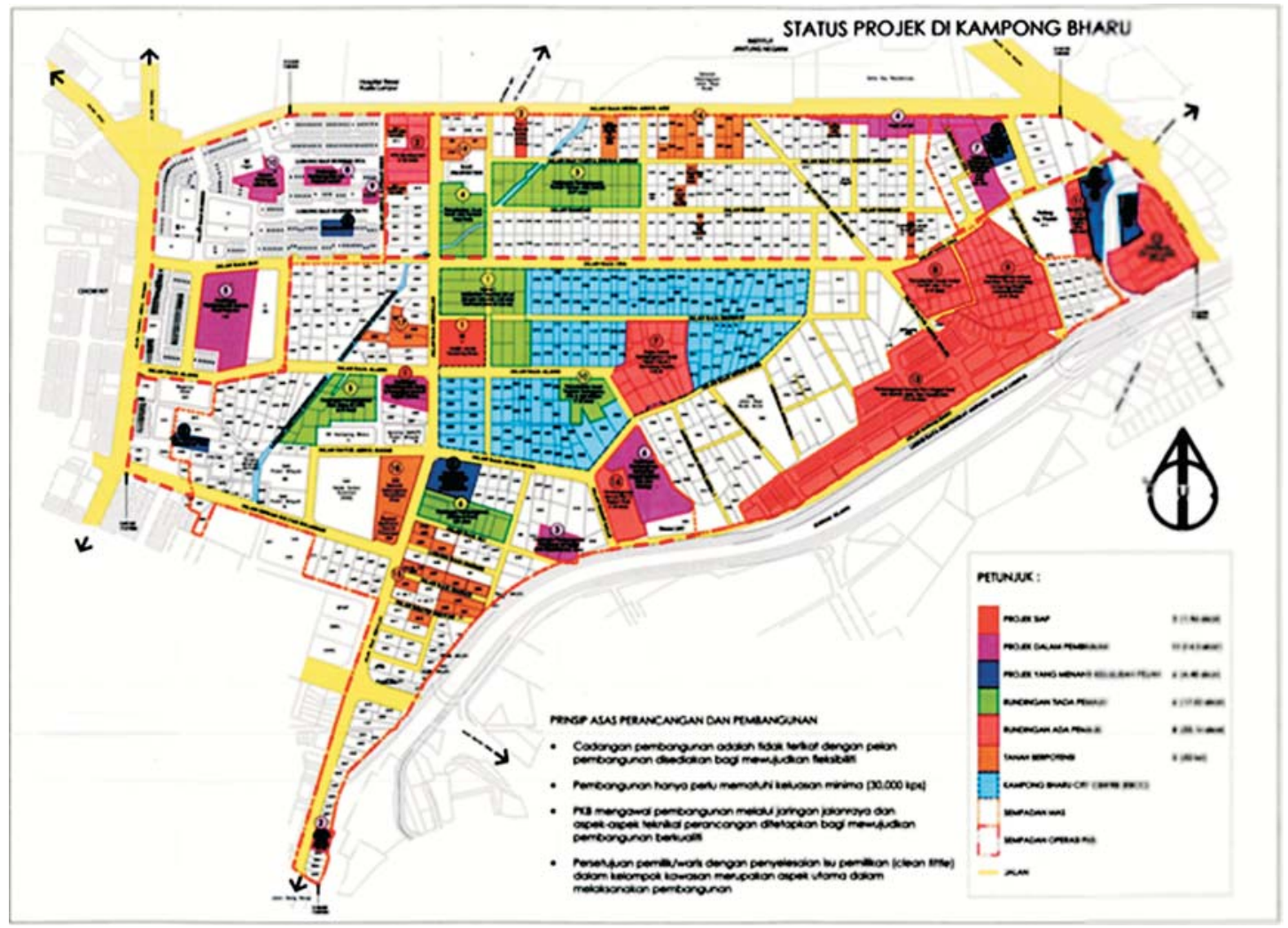

Figure 4: Current stage of development on 1st March 2018. 


\section{CONCLUSION}

The right formula to balance between development and maintaining unique value of an established community derives from one to another. However, through engagement and shared information with the stake holders, a compromise can be negotiated. As developing Asian countries seek economic growth and stability, they must also plan for an equitable sharing of the social and economic benefits derived from that growth. The special conditions and aspirations of the community must be understood, through engagement and shared information and the rights of community must be respected. Giving greater voice to urbanvillage dwellers will better align city redevelopment objectives with the interests and values of all the city's residents.

The role of the local authority is important not only in enforcement, but also in engagement and as mediators to facilitate and expediate proposed development. Political intervention is also important to steer the development to benefit the majority of the stake holder while not neglecting the aspirations of the minority.

\section{REFERENCES}

DBKL, 2004, "Kuala Lumpur Structure Plan 2020: A World Class City”.

Fujita, M. A., 2010, "Forays into Building Identity: Kampung to Kampong in the Kuala Lumpur Metropolitan Area", Journal of Architectural Education, Vol.63(2), 8-24.

Fainstein, S., 2012, "The Just City", Journal of Housing and the Built Environment, Vol.27:107-109.

Mohamed, S. and Zen., M.L., 2000, Sejarah Kampung Baru: Di Sini Awal Segalanya Bermula, Institut Alam dan Tamadun Melayu, Universiti Kebangsaan Malaysia, Bangi.

New Straits Times, Property Times, 2016, "Massive Make Over for Kampong Bharu”, viewed 11 September 2017.

PKB, 2014, "Draft Development Master Plan of Kampong Bharu", Viewed 11 September 2017, from http://www.pkb.gov.my/en/kampong-bharu-citizen/download.

Marilyn,T., 2007, "Community Participation in the Real World: Opportunities and Pitfalls in New Governance Spaces", Urban Studies, Vol.44(2):297-317.

Wiryomartono, B., 2013, "Urbanism, Place and Culture in the Malay World: The Politics of Domain from Pre-colonial to Post-colonial Era", City, Culture and Society, Vol.4(4), 217-227.

World Bank, 2016, viewed 3rd-Oct-2016 from http://www.worldbank.org/en/news/feature/2015/01/26/malaysia-amongmosturbanized-countries-in-east-asia. 